\title{
Do Norepinephrine and Estradiol Affect the Growth of Escherichia coli and Expressions of Mar Genes?
}

\author{
Norepinefrin ve Östradiol Escherichia coli'nin Üremesini ve Mar Genlerinin \\ Ekspresyonunu Etkiler mi?
}

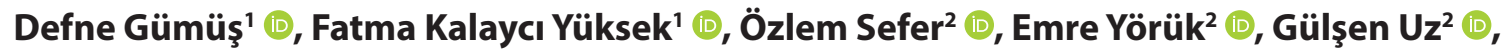 Mine Anğ Küçüker ${ }^{1}$ (D)}

'Department of Medical Microbiology, Faculty of Medicine, Istanbul Yeni Yüzyll University, Istanbul, Turkey

2Department of Molecular Biology and Genetics, Faculty of Arts and Science, Istanbul Yeni Yüzyıl University, Istanbul, Turkey

ORCID ID: D.G. 0000-0003-4070-6924; F.K.Y. 0000-0002-0028-5646; Ö.S. 0000-0002-2711-5938; E.Y. 0000-0003-2770-0157;

G.U. 0000-0001-9895-5187; M.A.K. 0000-0002-4809-3985

Cite this article as: Gümüş D, Kalaycı Yüksek F, Sefer Ö, Yörük E, Uz G, Anğ Küçüker M. Do norepinephrine and estradiol affect the growth of Escherichia coli and expressions of mar genes? Experimed 2021; 11(3): 200-6.

\begin{abstract}
Objective: Human hormones have been shown to regulate antibiotic resistance levels, pathogenicity, and growth of bacteria. In our study, we aimed to detect the possible effects of norepinephrine (NE) and estradiol (Est) on growth and expression of chromosomal multiple antibiotic resistance (mar) locus and related genes (ompF, marA, tolC, acrA, marR and acrB) in Escherichia (E) coli SPC105.
\end{abstract}

Material and Method: Serum supplemented SAPI (control) and serum SAPI containing norepinephrine $(0.0017 \mu \mathrm{g} / \mathrm{mL}, 0.04 \mu \mathrm{g} /$ $\mathrm{mL}$, and $100 \mu \mathrm{g} / \mathrm{mL}$ ) and estradiol $(0.4 \mathrm{ng} / \mathrm{mL}, 3 \mathrm{ng} / \mathrm{mL}, 300 \mathrm{ng} / \mathrm{mL})$ was used to grow E. coli SPC105. Growth alterations were determined using the turbidimetric method while the gene expression levels were examined by quantitative polymerase chain reaction (qPCR).

Results: It was shown that, NE and Est in all concentrations were shown to affect (reduce/enhance due to incubation periods or hormone concentrations) the growth of E. coli SPC105 apart from the high-level Est concentration. Expression levels of all six target genes were shown to be significantly enhanced in the presence of all concentrations of both NE and Est.

Conclusion: Our results constitute new data on the possible influences of these hormones on the growth and expressions of mar operon on transcriptional levels in the E. coli SPC105 strain.

Keywords: Norepinephrine, estradiol, mar operon, gene expression, growth, E. coli
ÖZ

Amaç: Hormonların bakterilerin virulansı, antibiyotik duyarlıığı ve üremesini düzenlediği bilinmektedir. Bu çalışmada, norepinefrin (NE) ve östradiolün (Est) Escherichia (E) coli SPC105 suşunun üremesi ve kromozomal çoğul antibiyotik direnci (mar) lokusu ve ilişkili genlerin ( $m a r A$, marR, ompF, $a c r A, a c r B$ ve tolC) ekspresyonu üzerine olası etkileri incelenmiştir.

Gereç ve Yöntem: E. coli SPC105 suşu serum ilave edilmiş SAPI (kontrol olarak) ve norepinefrin $(0,0017 \mu \mathrm{g} / \mathrm{mL}, 0,04 \mu \mathrm{g} / \mathrm{mL}$ ve 100 $\mu \mathrm{g} / \mathrm{mL}$ ) ile östradiol $(0,4 \mathrm{ng} / \mathrm{mL}, 3 \mathrm{ng} / \mathrm{mL}, 300 \mathrm{ng} / \mathrm{mL}$ ) eklenmiş serum-SAPI besiyerinde üretilmiştir. Üreme değişimleri turbidimetrik yöntem ile; gen ekspresyon düzeyleri ise kantitatif polimeraz zincir reaksiyonu (qPCR) ile araştırılmıştır.

Bulgular: Çalışmamızın sonucunda yüksek düzey Est dışında tüm denenen hormon konsantrasyonlarının E. coli SPC105 suşunun üremesi üzerine etkisi olduğu (inkübasyon süresine veya hormon konsantrasyonuna bağlı olarak baskılama/arttırma yönünde) gösterilmiştir. NE ve Est'nin tüm konsantrasyonlarının incelenen tüm hedef genlerin ekpresyonunu arttırdığı gösterilmiştir.

Sonuç: Sonuçlarımız incelenen bu iki hormonun E. coli SPC105 suşunun üremesi ve mar operonunun ekspresyonunda, transkripsiyonel seviyede, olası etkileri üzerine yeni bir veri ortaya koymuştur.

Anahtar Kelimeler: Norepinefrin, östradiol, mar operonu, gen ekspresyonu, üreme, E. coli 


\section{INTRODUCTION}

It is well known that not only host cells but also bacteria can sense and respond to human hormones as a result of a long coexistence and coevolution (1-3). Moreover, some microorganisms are also known to produce hormones which may be used to communicate with each other and to recognize their environment (quorum sensing pathway-QS) (1). It has been shown that human hormones may affect important biological processes such as growth, virulence, biofilm formations, antibiotic susceptibility, and expression levels of various genes of bacteria in a host during infection $(1,4-6)$.

The emergence and spread of multiple antibiotic resistances in bacteria can occur through two different mechanisms: via the acquisition of genes or chromosomal mutations $(7,8)$ and via intrinsic multidrug resistance (7) due to the regulation of chromosomal multiple antibiotic resistance (mar) locus. The conserved chromosomal marRAB operon in mar locus is found in Escherichia (E) coli and certain other enteric bacteria (Citrobacter spp., Klebsiella spp., Shigella spp., Enterobacter spp., Hafnia spp., Salmonella spp.) (7-11).

The marR, marA and marB genes in marRAB operon encode MarR, MarA and MarB. Although the function of the MarB protein is not clearly understood, it is known that MarA and MarR are transcriptional regulatory proteins which are capable of binding to DNA and regulating the expression of marRAB operon (MarR is an auto repressor, MarA is an auto activator) $(7,10)$. marR is inactivated by mutations or in the presence of certain phenolic ligands, antibiotics, and oxidative stress. If $\operatorname{mar} R$ is inactive, marRAB becomes depressed and marA expression occurs. So, the organism becomes multiple antibiotic resistant (quinolones, tetracycline, $\beta$-lactams, organic solvents, oxidative stress agents and household disinfectants) due to the regulation of the efflux pump and outer membrane porin genes by MarA activations (8,11-13). Specifically, MarA is a global transcriptional activator and it has been shown to regulate nearly forty different genes including $a c r A, a c r B$ and tolC encoding AcrAB-TolC multidrug resistance pump and ompF encoding outer membrane porin $\mathrm{OmpF}(10,14-16)$. Mar phenotypes were initially detected as being cross-resistant to quinolones, tetracycline, beta-lactams and various phenolic compounds (11). Bacteria become a mar phenotype when the AcrAB-TolC is over expressed and OmpF is down regulated (17).

In this study we aimed to detect the effects of norepinephrine (NE) (a stress hormone) and estradiol (Est) (a sex hormone) as host factors, on growth and expressions of the $a c r A, a c r B$, marA, marR, ompF and tolC genes associated with mar regulon in $E$. coli SPC105. These hormones are known to have specific phenolic groups like many other compounds such as various herbs, vegetables, and bile salts etc. which have also been shown to induce marRAB expression in E. coli SPC105 (17). The effects of these hormones on the expression of marRAB have not been investigated to date.

\section{MATERIAL AND METHOD}

\section{Strain}

The E. coli SPC105 strain carrying a chromosomal Pmarll:lacZ fusion at the $\lambda$ attachment site was used. This strain was kindly provided by Dr. Stuart Levy and Dr. Valérie Duval from Tufts University School of Medicine, USA. The organism was kept at $-80^{\circ} \mathrm{C}$ for quantitative polymerase chain reaction (qPCR) analysis.

\section{Medium, Hormones and Experimental Conditions}

Previously defined, 30\% (v/v) serum supplemented Standard American Petroleum Institute (serum-SAPI) was used (18). E. coli was inoculated in a hormone added SAPI medium to show the influences of hormones. Various levels of NE $(0.0017 \mu \mathrm{g} / \mathrm{mL}$, $0.04 \mu \mathrm{g} / \mathrm{mL}$ and $100 \mu \mathrm{g} / \mathrm{mL})$ and Est $(0.4 \mathrm{ng} / \mathrm{mL}, 3 \mathrm{ng} / \mathrm{mL}$ and $300 \mathrm{ng} / \mathrm{mL}$ ) were analyzed. The mean blood levels of health conditions were used to determine the low and medium concentrations. In cases of different pathogenic circumstances to which bacteria may also be exposed, high levels were also selected $(18,19)$. SAPI with no hormone was used as a control medium. We kept the hormone concentrations at $-20^{\circ} \mathrm{C}$ before the experiments and they were kept on ice during the experiments.

\section{Detection of Alterations on Growth}

E. coli SPC105 was inoculated in SAPI medium with no supplementation (as a control) and hormone added SAPI as mentioned above. The initial bacterial count $\left(4 \times 10^{6} \mathrm{CFU} / \mathrm{mL}\right)$ was prepared in a four times dilution (1:3) of overnight culture. Bacteria were incubated at $37^{\circ} \mathrm{C}$. Absorbance at $600 \mathrm{~nm}$ at the four, six- and 24-hour periods was measured to detect changes of growth. These conditions were tested in duplicate, and each experiment was performed twice.

\section{Detection of Alterations on Gene Expressions}

Gene expressions were determined according to transcriptional level of mRNAs in the presence and absence of host hormones (SAPI used as control).

\section{Total RNA Isolation and CDNA Synthesis}

E. coli SPC105 was grown in SAPI (control), SAPI+ $0.0017 \mu \mathrm{g} / \mathrm{mL}$ $\mathrm{NE}, \mathrm{SAPI}+0.04 \mu \mathrm{g} / \mathrm{mL} \mathrm{NE}, \mathrm{SAPI}+100 \mu \mathrm{g} / \mathrm{mL} \mathrm{NE}, \mathrm{SAPI}+0.4 \mathrm{ng} / \mathrm{mL}$ Est, SAPI $+3 \mathrm{ng} / \mathrm{mL}$ Est and SAPI $300 \mathrm{ng} / \mathrm{mL}$ Est for $16-24$ hours at $37^{\circ} \mathrm{C}$ while shaking at $200 \mathrm{rpm} .1 .5 \mathrm{~mL}$ of bacterial cultures was used in total RNA extraction using $0.5 \mathrm{~mL}$ TriPure reagent (Roche, Swiss). Total RNA extraction was carried out according to the manufacturer's recommendations. $0.5 \mathrm{ml}$ Tri-Pure was added to the mortar and homogenization was completed. Homogenized liquid samples were transferred to micro tubes. After the transfer, $100 \mu \mathrm{L}$ chloroform was added to each sample and shaken for 15 seconds to remove nucleoprotein complex. The samples were centrifuged for 15 minutes at $13,000 \mathrm{rpm}$ and the colorless upper phase was transferred to new micro tubes. $250 \mu \mathrm{L}$ isopropanol was added to the colorless phase and incubated at room temperature for 10 minutes. After the incubation, samples were centrifuged at $13,000 \mathrm{rpm}$ for 10 
minutes. Total RNA molecules precipitated to the bottom of the micro tube. The precipitated RNA molecules were solved with DEPC treated water. The isolated total RNAs were treated with $1 \mu \mathrm{L}$ DNasel ( $1 \mathrm{mg} / \mathrm{mL}$; Qiagen, Germany) at $37^{\circ} \mathrm{C}$ for $10 \mathrm{~min}$. The mixture was treated with $1 \mu \mathrm{L}$ EDTA $(50 \mathrm{mM})$ at $65^{\circ} \mathrm{C}$ for 5 min to stop any reaction. Quantitative and qualitative analysis of RNAs were performed with 1\% agarose gel electrophoresis and spectrophotometer measurement (Thermo, USA), respectively. $2 \mu \mathrm{g}$ total RNA molecules were converted with a cDNA commercial kit (Takara, Japan) according to the manufacturer's protocol. qPCR analysis was performed with $1 / 4$ diluted cDNA.

\section{Quantitative Polymerase Chain Reaction Analysis}

Eva Green (Bio-RAD, France) dye binding to double strand DNA (500ex/530em nm) was used in qPCR analysis. 16s rRNA gene was the selected housekeeping gene. Target genes' (marA, marR, ompF, acrA, acrB and tolC) expressions were normalized by expression of housekeeping gene. The $2^{-\Delta \Delta C T}$ formula developed by Livak and Schmittgen (20) was used to evaluate the expression levels. All analyses were carried out at least three times. $\mathrm{Cp}$ values were recorded and calculated using Quant Studio 5.0 software (Applied Biosystem, USA). qPCR was carried out in $16 \mu \mathrm{L}$ total volumes containing $1 \mathrm{X}$ Eva Green mix, 0.5 pmol forward and reverse primer (Table 1) and $2 \mu \mathrm{L}$ cDNA. Cycling conditions were as reported previously (21).

Table1. *Primers used in the gene expression analysis.

\begin{tabular}{|c|c|c|}
\hline Gene & Sequence $\left(5^{\prime}-3^{\prime}\right)$ & $\begin{array}{c}\text { Band size } \\
\text { (bp) }\end{array}$ \\
\hline 16S rRNA-f & CCA GGA TTT GAT YMT GGC & \multirow{2}{*}{532} \\
\hline 16S rRNA-r & GAA GGA GGT GWT CCA DCC & \\
\hline marA-f & TTA GGC CAA TAC ATC CGC AG & \multirow{2}{*}{128} \\
\hline marA-r & AAG GTT CGG GTC AGA GTT TG & \\
\hline marR-f & TGT AAA GGC TGG GTG GAA AG & \multirow{2}{*}{134} \\
\hline marR-r & GTT AAT TCT TGG TGC AGG TCC & \\
\hline ompF-f & GGTGTTGGCGGTTCTATCAG & \multirow{2}{*}{87} \\
\hline ompF-r & TTCTTGCAGGTTGGTACGG & \\
\hline$a c r A-f$ & CAT TGG TAC AGA ACG GTC AGG & \multirow{2}{*}{140} \\
\hline$a c r A-r$ & GTT CTC TTG TTT CAG CGT GC & \\
\hline$a c r B-f$ & TTC CAT CTT CGC CAG TTC AG & \multirow{2}{*}{113} \\
\hline$a c r B-r$ & TCA TCG CAG AGT TTA ACG GC & \\
\hline tolC-f & CGG GAT TTC TGA CAC CTC TTA TAG & \multirow{2}{*}{144} \\
\hline tolC-r & ACC TGC GAG TTA ACC ATT CC & \\
\hline
\end{tabular}

*Primer sequences were prepared for previous study (22).

(https://eu.idtdna.com/scitools/Applications/RealTimePCR/)

\section{Statistical analysis}

The influences of hormones on the growth of standard strains were detected by two-way ANOVA Bonferroni post-test. Additionally, gene expression levels (u/down regulations) were calculated using the one-way ANOVA unpaired t-test.

\section{RESULTS}

\section{Alterations on Growth}

The growth of E. coli SPC105 was shown to be affected in the presence of NE depending on hormone concentrations. The presence of low-level NE significantly decreased $(p<0.001)$ the growth of the strain; however the growth was significantly increased $(p<0.001)$ in the presence of both medium and high concentrations of NE after 4, 6 and 24 hours incubation (Figure 1).
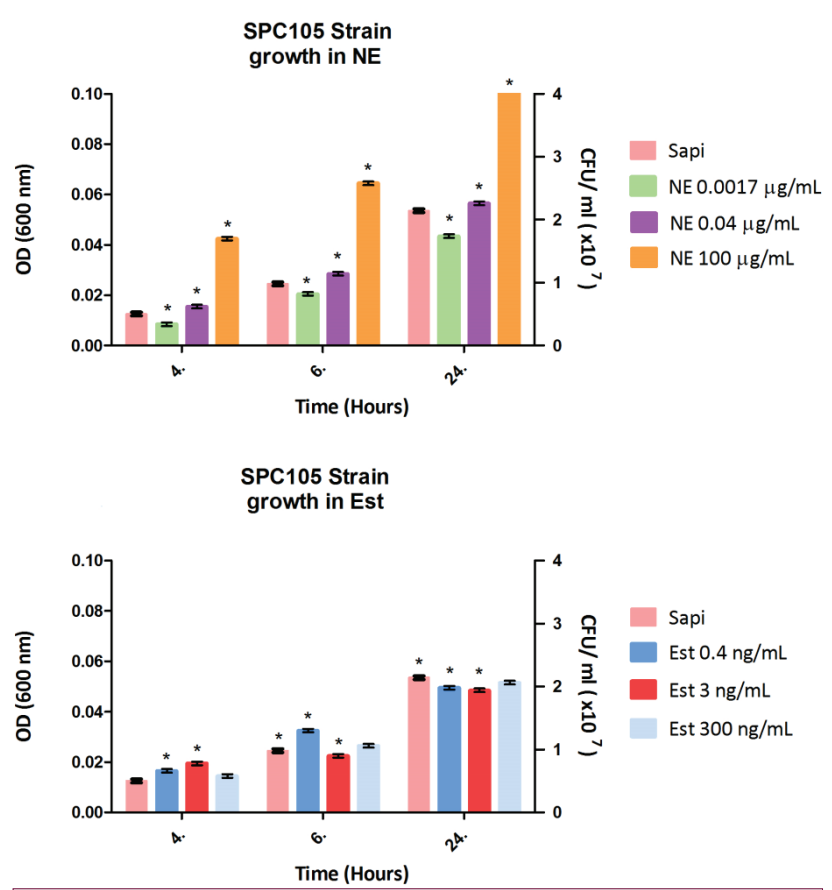

Figure 1. Effects of different concentrations of NE and Est on growth of E. coli SPC105. SAPI without any of hormones was used as control.

Growth alterations were performed using a two-way ANOVA Bonferroni post-test; * $p<0.001$

Both low and medium concentrations of Est enhanced the growth of the strain significantly at the 4- and 6-hour periods $(p<0.001)$. But in contrast, when the incubation time was extended, the growth was shown to be reduced by low and medium levels of Est at 24 hours incubation $(p<0.001)$. A high level of Est was shown to have no influence on growth of $E$. coli SPC105 ( $p>0.05)$ (Figure 1).

\section{Alterations on Gene Expressions}

High quality total RNAs with $\Delta_{260 / 280} \sim 1.9-2.0$ were obtained using a commercial total RNA isolation kit. Converted RNAs were subjected to qPCR and Rt-PCR assays. The melting scores and $E$ values ranged between $90-100 \%$ and $1.8-2.1$ respectively. These values showed that qPCRs were run efficiently. The minimum and maximum $\mathrm{Cp}$ values ranged between 20.8427.80, 21.17-28.20, 20.27-27.17, 20.59-26.86, 20.74-27.48, 20.06-26.26 and 14.80-18.82 marA, marR, acrA, acrB, tolC, ompF 
and $16 \mathrm{~S}$ rRNA genes, respectively. $2^{-\triangle \Delta C T}$ values changed between $2.53 \pm 0.23-13.92 \pm 2.44,2.96 \pm 0.16-15.48 \pm 1.3,2.18 \pm 0.22-$ $14.09 \pm 1.7,1.85 \pm 0.004-12.44 \pm 0.74,2.12 \pm 0.17-11.91 \pm 0.99$ and 1.39 $\pm 0.04-12.27 \pm 1.12$ for $\operatorname{mar} A, \operatorname{mar} R, a c r A, a c r B$, tolC and ompF genes in different experimental conditions.

\section{Fold changes in six target genes' expressions}

Expressions of all six genes were found to have increased in the presence of both NE and Est in all concentrations. Significant differences were detected between the control and included hormones in SAPI for each gene $(p<0.05-p<0.001)$ (Figure 2 ).

\section{DISCUSSION}

Bacteria maintain a community behavior and adapt to their own habitats (host) via various chemical signaling pathways. These molecules which are known as quorum sensing molecules (QS) are essential for survival and optimizing of their
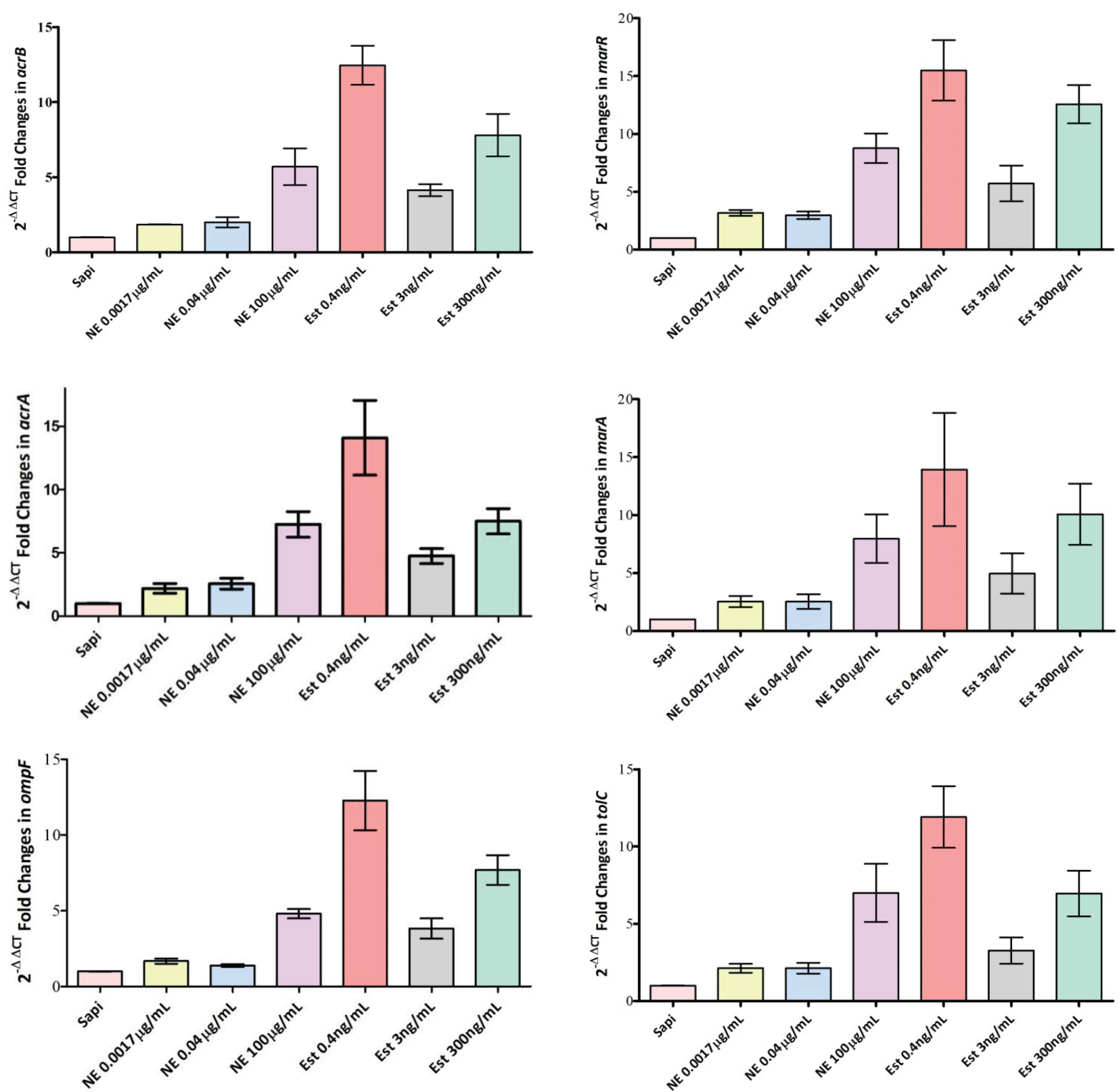

Figure 2. Fold-changes in mar expressions on mRNA transcriptional level. 
gene expressions, virulence mechanisms, and antibiotic resistance (23-25). It is well known that, not only bacteria-bacteria communication but also bacteria-host communication is very essential, this is known as inter kingdom signaling. According to previous studies, it is clear that to maintain this cell-to-cell communication, bacteria may use certain host factors such as hormones. Stress for instance, is very important to generate an unfavorable condition for the host which leads to them becoming more susceptible to infections and even the immune functions are induced. Therefore, an emergent research area, "Microbial Endocrinology", has gained importance to investigate how these hormones could affect the biological properties of bacteria $(1,18)$. In our study, the possible effects of NE (a stress hormone) and Est (a gender hormone) on growth and expressions of certain genes associated with mar regulon of $E$. coli SPC105 were investigated. These were chosen as examples of human hormones with different effects and they also carry phenolic groups in their structure.

Previous investigations have also shown that the enteric nervous system in mammalian hosts is the primary site for NE to reproduce and to be utilized. The gut is the main habitat for NE; that's why most of the studies focusing on host-microbe communication target $E$. coli strains $(1,26)$. Catecholamines such as $\mathrm{NE}$, regulate the biological properties of microorganisms by the iron accessing mechanism (1). It is very clear that sex hormones such as Est and progesterone also influence the growth and gene regulation mechanisms of bacteria because they replace vitamin $\mathrm{K}(1,5,27)$. Also, they have proven to have protective activity against infections via induction of bactericidal activities of proinflammatory cells and innate and adaptive immune responses of the host (27-29). Previous investigations have shown that these host derived hormones could also be metabolized by fecal bacteria to use them as carbon and energy sources $(1,27,29)$. Numerous studies have reported that host hormones have certain effects on the various gene expressions of bacteria related with enzyme metabolism, virulence, iron uptake systems, stress responses and antibiotic resistance as mentioned above (21,30-33).

The influence of hormones on the growth of various bacteria has been shown in many studies $(1,4,5,18,21,32-35)$. Gümüş et al. investigated the SPC105 strain to show the possible effects of human insulin and glucose on growth and expression levels of mar operon (22). They have shown that in a rich culture medium (TSB), the growth of SPC105 was shown to have decreased in the presence of $200 \mu \mathrm{U}$ insulin $+0.1 \%$ glucose and $0.1 \%$ glucose; however, $20 \mu \mathrm{U}$ insulin and $200 \mu \mathrm{U}$ insulin did not affect the growth of bacterium. Therefore, it may be concluded that, in standard, rich medium the effects of hormones cannot be detected effectively which led us to select serum-SAPI in this study.

In the present study we detected alterations of growth depending on hormone types and/or concentrations. NE for instance, significantly enhanced the growth of the SPC105 E. coli strain with medium and high-level concentrations tested at the four, six and 24 hours periods. According to previous studies, this effect may be related to iron acquisition from the transferrin (serum iron-binding protein) and transferring to the bacteria $(1,26,33,36)$. Although Kornman and Loeshe reported that Est could inhibit the growth of Bacteroides species (5), our results showed enhancement of growth in the presence of low and medium Est concentrations at 4 and 6 hours; however, when the incubation time was increased to 24 hours, the growth was found to be reduced. We found no induction on the growth of bacteria in the presence of high-level Est. Therefore, we suggest that growth alterations could be associated with exposure time, hormone concentration, and the strain tested.

Previous studies have shown that host hormones could affect the expression levels of antimicrobial resistance genes in Candida species, Staphylococcus aureus, E. coli, Edwardsiella (3741). Plotkin and Konakieva suggested that microorganisms sense different environmental signals and develop various genetic modifications such as chromosomal mutations or up regulation of efflux pumps to defend themselves (37). Another previous study focusing on expression levels of mar operon located in SPC105 strain which was examined in the present study showed a significant down regulation in the expression levels of marA and marR in the presence of $200 \mu \mathrm{U} / \mathrm{mL}$ insulin, $0.1 \%$ glucose and $200 \mu \mathrm{U} / \mathrm{mL}$ insulin $+0.1 \%$ glucose. The expression of acrA was also decreased in the presence of 200 $\mu \mathrm{U} / \mathrm{mL}$ insulin (22) which may be due to a reduction in growth of bacterium as mentioned above. Cohen et al. showed the significant six fold increase in $\beta$-galactosidase activity in the E. coli SPC105 strain in the presence of salicylate and because it carries mar promoter-lacZ fusion on the chromosome, this increase also denotes the induction of mar operon (42). The expression level of mar operon and growth alterations were also investigated in a study by Maira-Litrán et al. by comparing two different culture media (LB and CDM; nutrient rich and poor, respectively) in planktonic and biofilm conditions. They showed that, $\beta$-galactosidase levels were higher in CDM rather than LB. When the E. coli SPC105 was grown in CDM medium, via biofilm conditions, the expression of mar was not induced (43). In the present study, gene expression levels of six target genes (marA, marR, ompF, acrA, acrB and tolC) associated with chromosomal multiple antibiotic resistance were found to be increased in the presence of both NE and Est with all three concentrations. It is known that MarR suppresses marRAB operon, but marRAB transcription occurs if MarR suppression is removed which may be due to mutations or presence of phenolic compounds, oxidative stress inducers and antibiotics $(11,16)$. In our study we assumed that these hormones enhanced the expression of marR, but in the meantime MarR may bind to NE and Est which can lead to derepression of MarR.

Multidrug resistance is associated with marRAB operon due to the activation of MarA, which yields both up regulations of the AcrAB-TolC efflux pump and down regulation of the outer membrane porin OmpF $(10,42,44)$. In the present study, the up regulations of $a c r A, a c r B$, and tolC genes were shown to be con- 
sistent with previous studies; but on the other hand our results have also suggested that, hormones affected the expression levels of ompF independently from marA.

In conclusion, our results constitute new data on the possible effects of these two mammalian hormones (NE and Est) on the growth and on mar operon's expressions on the transcriptional level in the E. coli SPC105 strain. It may be concluded that these effects depended on hormone concentrations, exposure time, medium used and strain tested. Also, during exposure to certain environmental factors, genes associated with mar operon could be affected independently from each other ( $\operatorname{mar} R-$ marA) and from the mechanism identified in previous studies $(12,13)$. As a future perspective, it seems that we are going to look for an answer as to whether, during an infection, hormones as one of the environmental factors in a human host could lead to multi drug resistance in different type of bacteria.

Ethics Committee Approval: Ethics committee approval is not required because of no material or experimental animal that would require permission.

Peer-review: Externally peer-reviewed.

Author Contributions: Conception/Design of Study - D.G., F.K., M.K.; Materials - D.G., F.K., E.Y., Ö.S., G.U.; Data Collection - D.G., F.K., E.Y., Ö.S., G.U.; Analysis and/or Interpretation - D.G., F.K., M.K.; Drafting Manuscript - D.G., F.K., M.K.; Final Approval and Accountability - D.G., F.K., M.K.

Conflict of Interest: The authors have no conflict of interest to declare.

Financial Disclosure: The authors declared that this study has received no financial support.

Etik Komite Onayı: Bu calışmada, etik komite iznine gerek duyulacak bir materyal ya da deney hayvanı kullanılmamıştır.

Yazar Katkıları: Çalışma Konsepti/Tasarımı - D.G., F.K., M.K.; Materyal: D.G., F.K., E.Y., Ö.S., G.U.; Veri Toplama - D.G., F.K., E.Y., Ö.S., G.U.; Veri Analizi/Yorumlama - D.G., F.K., M.K.; Yazma - D.G., F.K., M.K.; Son Onay ve Sorumluluk - D.G., F.K., M.K.

Çıkar Çatışması: Yazarlar çıkar çatışması bildirmemişlerdir.

Finansal Destek: Yazarlar bu çalışmada finansal destek almadıklarını beyan etmişlerdir.

\section{REFERENCES}

1. Lyte M, Freestone PP. Microbial Endocrinology: Inter kingdom signaling in Infectious Disease and Health. New York: Springer; 2010. [CrossRef]

2. LeRoith D, Shiloach J, Roth J, Lesniak MA. Insulin or a closely related molecule is native to Escherichia coli. Journal of Biological Chemistry 1981; 256(13): 6533-6. [CrossRef]

3. Miller MB, Bassler BL. Quorum sensing in bacteria. Annu Rev Microbiol 2001; 55: 165-99. [CrossRef]

4. Plotkin BJ, Viselli SM. Effect of insulin on microbial growth. Curr Microbiol 2000; 41: 60-4. [CrossRef]
5. Kornman KS, Loesche WJ. Effects of estradiol and progesterone on Bacteroides melaninogenicus and Bacteroides gingivalis. Infect and Immun 1982; 35(1): 256-63. [CrossRef]

6. Delcenserie V, LaPointe G, Charaslertrangsi T, Rabalski A, Griffiths MW. Glucose decreases virulence gene expression of Escherichia coli O157: H7. J Food Protect 2012; 75(4): 748-52. [CrossRef]

7. Ruiz C, Levy SB. Many chromosomal genes modulate MarA-mediated multidrug resistance in Escherichia coli. Antimicrobiol Agents Chemother 2010; 54(5): 2125-34. [CrossRef]

8. Randall LP, Woodward MJ. The multiple antibiotic resistance (mar) locus and its significance. Res Vet Sci 2002; 72: 87-93. [CrossRef]

9. Kunonga NI, Sobieski RJ, Crupper SS. Prevalence of the multiple antibiotic resistance operon (marRAB) in the genus Salmonella. FEMS Microbiol Lett 2000; 187(2): 155-60. [CrossRef]

10. Vinué L, McMurry LM, Levy SB. The 216-bp marB gene of the marRAB operon in Escherichia coli encodes a periplasmic protein which reduces the transcription rate of marA. FEMS Microbiol Lett 2013; 345(1): 49-55. [CrossRef]

11. Weston N, Sharma P, Ricci V, Piddock LJ. Regulation of the AcrAB-TolC efflux pump in Enterobacteriaceae. Res Microbiol 2018; 169(7-8): 425-31. [CrossRef]

12. Alekshun MN. Levy SB. The mar regulon: multiple resistances to antibiotics and other toxic chemicals. Trends Microbiol 1999; 7(10): 410-13. [CrossRef]

13. Alekshun MN, Levy SB. The Escherichia coli mar locus-Antibiotic resistance and more. ASM News 2004; 70(10): 451-56.

14. Lankester A, Ahmed S, Lamberte LE, Kettles RA, Grainger DC. The Escherichia coli multiple antibiotic resistance activator protein represses transcription of the lac operon. Biochem Society Transact 2019; 47(2): 671-77. [CrossRef]

15. Zgurskaya HI, Krishnamoorthy G, Ntreh A, Lu S. Mechanism and function of the outer membrane channel TolC in multidrug resistance and physiology of enterobacteria. Frontiers Microbiol 2011; 2: 189. [CrossRef]

16. Misra R, Bavro VN. Assembly and transport mechanism of tripartite drug efflux systems. Biochimica et Biophysica Acta (BBA) Proteins Proteomics 2009; 1794(5): 817-25. [CrossRef]

17. Rickard AH, Lindsay S, Lockwood GB, Gilbert P. Induction of the mar operon by miscellaneous groceries. J Appl Microbiol 2004; 97(5): 1063-68. [CrossRef]

18. Lyte $\mathrm{M}$, Ernst $\mathrm{S}$. Catecholamine induced growth of gram negative bacteria. Life Sci 1992; 50(3): 203-12. [CrossRef]

19. Zhang X, Essmann M, Burt ET, Larsen B. Estrogen effects on Candida albicans: a potential virulence-regulating mechanism. J Infect Dis 2000; 181(4): 1441-46. [CrossRef]

20. Livak KJ, Schmittgen TD. Analysis of relative gene expression data using real-time quantitative PCR and the $2-\triangle \triangle C T$ method. Methods 2001; 25: 402-08. [CrossRef]

21. Gumus D, Yoruk E, Kalayci-Yuksek F, Uz G, Topal-Sarikaya A, Ang-Kucuker $M$. The effects of insulin and glucose on different characteristics of a UPEC: alterations in growth rate and expression levels of some virulence genes. Clin Lab 2017; 63(10): 1589-97. [CrossRef]

22. Gümüş D, Yüksek FK, Uz G, Bayraktar A, Köseoğlu P, Ofluoğlu Y, et al. The effects of insulin and glucose on growth and expression of mar regulon in E. coli. Turkish J Clin Lab 2019; 10(2): 209-16.

23. Williams P. Quorum sensing, communication and cross-kingdom signalling in the bacterial world. Microbiol 2007; 153(12): 3923-38. [CrossRef]

24. Sperandio V. Torres AG, Jarvis B, Nataro JP, and Kaper JB. Bacteria-host communication: the language of hormones. Proc Natl Acad Sci USA 2003; 100: 8951-6. [CrossRef] 
25. Hughes DT, Sperandio V. Inter-kingdom signalling: communication between bacteria and their hosts. Nature Reviews Microbiology 2008; 6(2): 111-20. [CrossRef]

26. Lyte M, Freestone PP, Neal CP, Olson BA, Haigh RD, Bayston R, et al. Stimulation of Staphylococcus epidermidis growth and biofilm formation by catecholamine inotropes. Lancet 2003; 361 (9352): 130-5. [CrossRef]

27. García-Gómez E, González-Pedrajo B, Camacho-Arroyo I. Role of sex steroid hormones in bacterial-host interactions. BioMed Res International 2013; 2013: 928290. [CrossRef]

28. Saia RS, Garcia FM, Cárnio EC. Estradiol protects female rats against sepsis induced by Enterococcus faecalis improving leukocyte bactericidal activity. Steroids 2015; 102: 17-26. [CrossRef]

29. Patt MW, Conte L, Blaha M, Plotkin BJ. Steroid hormones as interkingdom signaling molecules: Innate immune function and microbial colonization modulation. AIMS Molecul Sci 2018; 5(1): 117-30. [CrossRef]

30. Plotkin BJ, Roose RJ, Erikson Q, Viselli SM. Effect of androgens and glucocorticoids on microbial growth and antimicrobial susceptibility. Curr Microbiol 2003; 47(6): 514-20. [CrossRef]

31. Jerse $A E$, Wu $H$, Packiam M, Vonck RA, Begum A, Garvin LE. Estradiol-treated female mice as surrogate hosts for Neisseria gonorrhoeae genital tract infections. Frontiers Microbiol 2011; 2: 107. [CrossRef]

32. Intarak N, Muangsombut V, Vattanaviboon P, Stevens MP, Korbsrisate $\mathrm{S}$. Growth, motility and resistance to oxidative stress of the melioidosis pathogen Burkholderia pseudomallei are enhanced by epinephrine. Pathogens Dis 2014; 72(1): 24-31. [CrossRef]

33. Li W, Lyte M, Freestone PP, Ajmal A, Colmer-Hamood JA, Hamood AN. Norepinephrine represses the expression of toxA and the siderophore genes in Pseudomonas aeruginosa. FEMS Microbiol Lett 2009; 299(1): 100-09. [CrossRef]

34. Yokoyama M, Hinode D, Masuda K, Yoshioka M, Grenier D. Effect of female sex hormones on Campylobacter rectus and human gingival fibroblasts. Oral Microbiol Immunol 2005; 20(4): 239-43. [CrossRef]
35. Gonullu N, Kucukbasmaci O, Buyukbaba-Boral O, Ang-Kucuker M. The influence of glucose added urine on the in vitro antimicrobial activity of various antibiotics. Indian J Med Res 2008; 128(5): 663-5.

36. Roberts A, Matthews JB, Socransky SS, Freestone PPE, Williams PH, Chapple ILC. Stress and the periodontal diseases: effects of catecholamines on the growth of periodontal bacteria in vitro. Oral Microbiol Immunol 2002; 17(5): 296-303. [CrossRef]

37. Plotkin BJ, Konakieva MI. Attenuation of antimicrobial activity by the human steroid hormones. Steroids 2017; 128: 120-7. [CrossRef]

38. Micheli MD, Bille J, Schueller C, Sanglard D. A common drug-responsive element mediates the upregulation of the Candida albicans $A B C$ transporters CDR1 and CDR2, two genes involved in antifungal drug resistance. Molecular Microbiol 2002; 43(5): 1197214. [CrossRef]

39. Banerjee D, Martin N, Nandi S, Shukla S, Dominguez A, Mukhopadhyay G, Prasad R. A genome-wide steroid response study of the major human fungal pathogen Candida albicans. Mycopathologia 2007; 164(1): 1-17. [CrossRef]

40. Peng B, Ma YM, Zhang JY, Li H. Metabolome strategy against Edwardsiella tarda infection through glucose-enhanced metabolic modulation in tilapias. Fish \& Shellfish Immunol 2015; 45(2): 86976. [CrossRef]

41. Allison KR, Brynildsen MP, Collins JJ. Metabolite-enabled eradication of bacterial persisters by aminoglycosides. Nature 2011; 473(7346): 216-20. [CrossRef]

42. Cohen SP, Levy SB, Foulds J, Rosner JL. Salicylate induction of antibiotic resistance in Escherichia coli: activation of the mar operon and a mar-independent pathway. J Bacteriol 1993; 175(24): 785662. [CrossRef]

43. Maira-Litrán T, Allison DG, Gilbert P. Expression of the multiple antibiotic resistance operon (mar) during growth of Escherichia coli as a biofilm. J Appl Microbiol 2000; 88(2): 243-7. [CrossRef]

44. Chubiz LM, Rao CV. Role of the mar-sox-rob regulon in regulating outer membrane porin expression. J Bacteriol 2011; 193(9): 225260. [CrossRef] 